\title{
Tourism And Economic Growth In Kenya: An Empirical Investigation
}

Obadiah N. Kibara, University of South Africa, South Africa

Nicholas M. Odhiambo, University of South Africa, South Africa

Josephine M. Njuguna, University of South Africa, South Africa

\begin{abstract}
In this study, we examine the dynamic relationship between tourism sector development and economic growth - using annual time-series data from Kenya. The study attempts to answer one critical question - "Is tourism development in Kenya pro-growth?" The study uses an ARDLbounds testing approach to examine these linkages and also incorporates trade as an intermittent variable between tourism development and economic growth in a multivariate setting. The results of our study show that there is a uni-directional causality from tourism development to economic growth. The results are found to hold irrespective of whether the causality is estimated in the short run and long run. Other results show that international tourism Granger-causes trade, while trade Granger-causes economic growth in Kenya in both the short and the long run.
\end{abstract}

Keywords: Kenya; Tourism Development; Economic Growth

\section{INTRODUCTION}

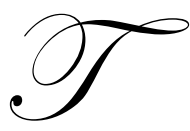

he relationship between tourism development and economic growth has attracted numerous studies in recent years. Studies have shown that development of the tourism sector stimulates economic growth both at the national and local levels. It promotes the growth of agricultural, industrial and service sectors (Yamakawa, 2007). As a labour-intensive industry, tourism provides a wide range of employment, thereby improving the welfare of the nationals.

According to Croes and Vanegas (2008), the role of tourism development can be linked to Vanegas and Croes $(2003,2004)$ called "the democratization of the dollar". According to Vanegas and Croes (2003, 2004), tourism development leads to the transfer of wealth and income from residents of developed and developing countries to residents of developing and least developed countries, thereby leading to mass generation of employment opportunities and ample participation for all sectors of the economy which, in the end, increases income of developing countries as well as the standard of living (Croes and Vanegas, 2008).

Although a number of studies have been conducted to examine the relationship between tourism development and economic growth, there has been no unanimous agreement on the direction of causality between these two important economic variables. While some studies argue that it is the growth of the tourism sector that causes economic growth, others argue that it is the real sector development that leads to the invasion sector development. Between these two extremes, there are those who posit that these sectors Granger-cause each other.

Using novel empirical techniques in this study, we examine the dynamic causal relationship between international tourism development and economic growth in Kenya. The study attempts to answer one critical question - "Does the development of the tourism sector in Kenya lead to economic growth?" 


\section{The Dynamics of Tourism Sector Development in Kenya}

Kenya is one of the leading tourist destinations in sub-Saharan Africa and has significant potential for tourism growth. The country has embraced tourism as a tool for socioeconomic development, as is the case with many Third World countries. The country is endowed with unique tourist attractions consisting of tropical beaches, diverse wildlife in natural habitats, scenic landforms, archaeological sites, and a rich indigenous cultural heritage which combine to form a unique tourist product. However, beach tourism and wildlife safaris remain the focus for Kenya's tourism industry.

The tourism sector in Kenya plays a significant role in the country's economic development in terms of foreign exchange earnings, job creation, and poverty alleviation, particularly in the rural areas. Tourism accounts for about 10 percent of the Gross Domestic Product, making it the third largest contributor to the GDP - after agriculture and manufacturing (GoK, 2011). Indeed, due to its high multiplier effects, tourism in Kenya acts as a stimulus to the growth of other sectors, including agriculture, transport, entertainment, crafts/souvenirs, as well as trade and industry.

The development of tourism in Kenya can be traced from three distinct phases. The first phase relates to the exploration period, before 1890, when various travellers arrived at the East African coast. During this period, some travellers engaged in peaceful and legitimate trade, while others waged wars, razed towns, or captured and sold slaves (Ouma, 1970). With the exception of slave traders and the occasional European explorers and missionaries in the $19^{\text {th }}$ century, such as Dr. Livingstone, Stanley, Burton, Krapf and Teleki to the interior of East Africa, virtually no foreigners had penetrated the African inland. It should be noted that the contemporary form of tourism did not exist during the period in question. However, this period is remarkable, as it opened up the region to the outside world.

The second phase was the British colonial era (1895-1962). During this period, the country witnessed the development of the rail, road, and air transport systems. New hotels were established and a number of tourist attractions, such as national parks and game reserves were gazetted for conservation and preservation (Akama, 1999). Pioneer national parks include the Nairobi National Park in 1946, Amboseli National Park in 1947, Tsavo National Park in 1948, and Mt. Kenya National Park in 1949. At the beginning of this phase, the British colonial authorities allowed a small number of adventurers to penetrate the game-rich interior parts of the country. Indeed, visitors had to be both hardy enough to withstand the long sea voyages and wealthy enough to organize scientific or hunting safaris, employing veritable armies of porters and guides (Rajotte, 1983). However, the Great Depression of the 1930s hampered further expansion of tourism from Europe and North America.

After the Second World War, tourism was developed as a regional activity in East Africa (Kenya, Uganda \& Tanzania) by the East African Tourist Travel Association founded in 1947. The next decade witnessed private investment in hotel constructions in Nairobi, the game parks and the Kenya Coast, as well as establishment of tour companies for both game hunting and photo safaris. However, the political climate in Kenya - the Mau Mau uprising and the state of emergency (1952-1957) - discouraged a significant number of potential tourists to visit Kenya. Nevertheless, significant development was experienced during this phase, as was demonstrated by the number of the tourist arrivals. In 1950, for instance, Kenya received 24,060 tourists, but this number more than doubled to 61,350 tourists in 1963 (Ouma, 1970). Thus, this phase of development was characterized by deliberate planning of the tourism infrastructure and associated facilities.

The last phase of development is what Akama (1999) refers to as the post-colonial era. After the attainment of independence from the British colonial government in 1963, Kenya continued with the colonial policy of economic liberalization, and deliberately favoured the development of tourism, arguing that the investment in the tourist sector would later bring economic returns which could be used for investments in more essential development sectors (Rajotte, 1983).

Indeed, Kenya's second development plan emphasizes that it is the government's policy that private investment in activities, such as hotels and tour operations, should be continued and encouraged, while the government's investment aims particularly to eliminate bottlenecks and provide infrastructure (GoK, 1970). In this regard, the government undertook specific policy initiatives to promote the rapid expansion of tourism. 
Since independence in 1963, Kenya has made a number of initiatives which are aimed at boosting the tourism sector, thereby making Kenya one of Africa's most popular destinations. In 1965, for example, Kenya established a tourism development corporation called the Kenya Tourism Development Corporation (KTDC). The responsibilities of KTDC included the administration of tourism investment initiatives, as well as monitoring the establishment and operation of tourism and hospitality facilities (Dieke, 1991).

Cognizant of the socioeconomic significance of the tourism industry in Kenya, in 1966 the government established a tourism ministry called "The Ministry of Tourism and Wildlife (MTW)". The main aim of this ministry was twofold: 1) to oversee the overall formulation and implementation of the country's tourism policy and 2) to manage Kenya's tourism and wildlife resources. In 1969, the country's first statement on National Tourism Policy was set out in Sessional Paper No. 8 of 1969. In order to accelerate the development of the tourism and hospitality facilities, a Tourism Master Plan was initiated in 1995.

In 2003, the government of Kenya identified tourism as one of the sectors that had contributed significantly to poverty alleviation and employment creation (GoK, 2003). This culminated in the establishment of Kenya's first comprehensive tourism policy in 2006. The overall aim of Kenya's National Tourism Policy, which is yet to be ratified, is to ensure that tourism retains its position as a leading export and a major vehicle for job creation, poverty reduction, and wealth creation for Kenyans in the future (GoK, 2006).

The contributions of the tourism industry in Kenya have also been recently embraced by Kenya's long-term national strategy known as "Vision 2030 for Kenya". This strategy identifies tourism as one of the six priority sectors that will spur on the economy. The other sectors included in this vision are agriculture and livestock, wholesale and retail trade, manufacturing, finance, and business-process outsourcing. The vision for the tourism sector is to "become a top-ten long-haul tourist destination in the world that offers a high-value, diverse and distinctive visitor experience."

The most recent tourism policy initiative in Kenya was the enactment of the Tourism Bill of 2010 in September 2011 (i.e., the Tourism Act 2010). The Act provides for a national tourism strategy that will prescribe the principles, objectives, standards, indicators, procedures, and incentives for the development, management, and marketing of sustainable tourism in Kenya (GoK, 2010). Figures 1 and 2 show the trends of international tourism arrivals and receipts in Kenya during the period 1999-2010, when compared to 1983.

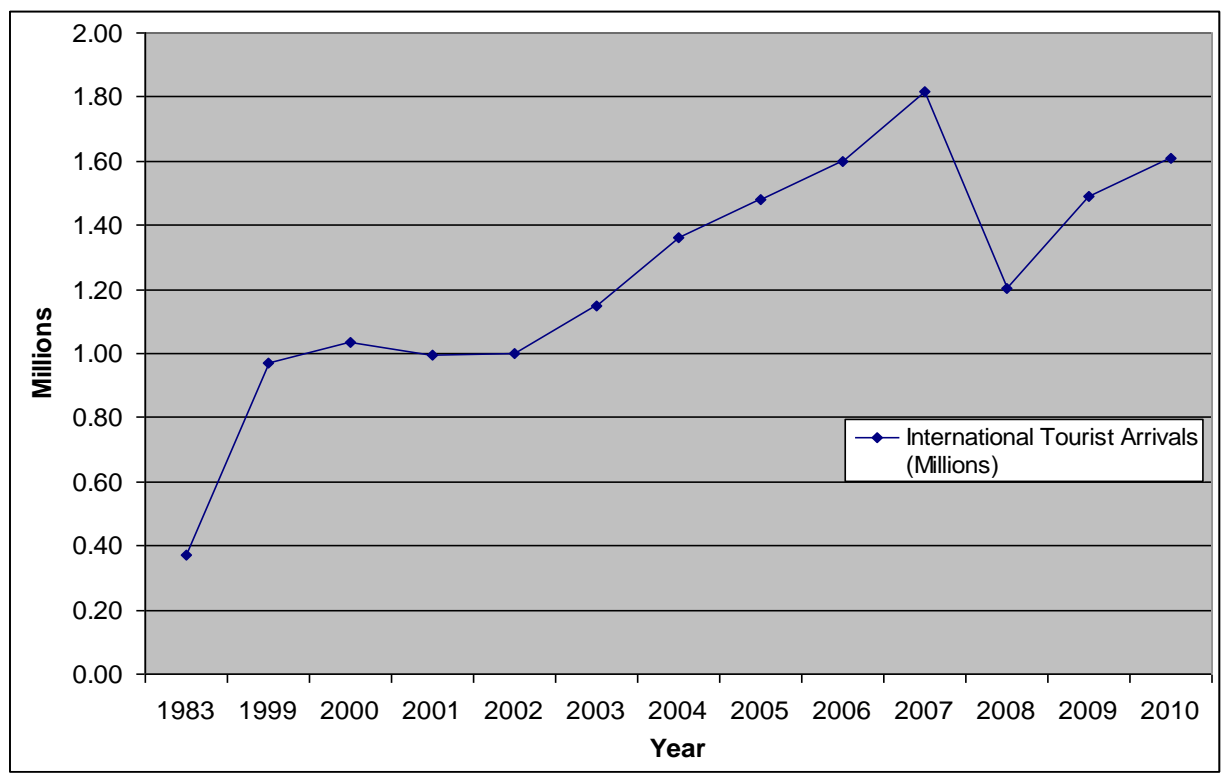

Figure 1: International Tourist Arrivals in Kenya during the Period 1999-2010 as Compared to 1983

Source: Compiled from Kenya Economic Survey (Various Issues) 


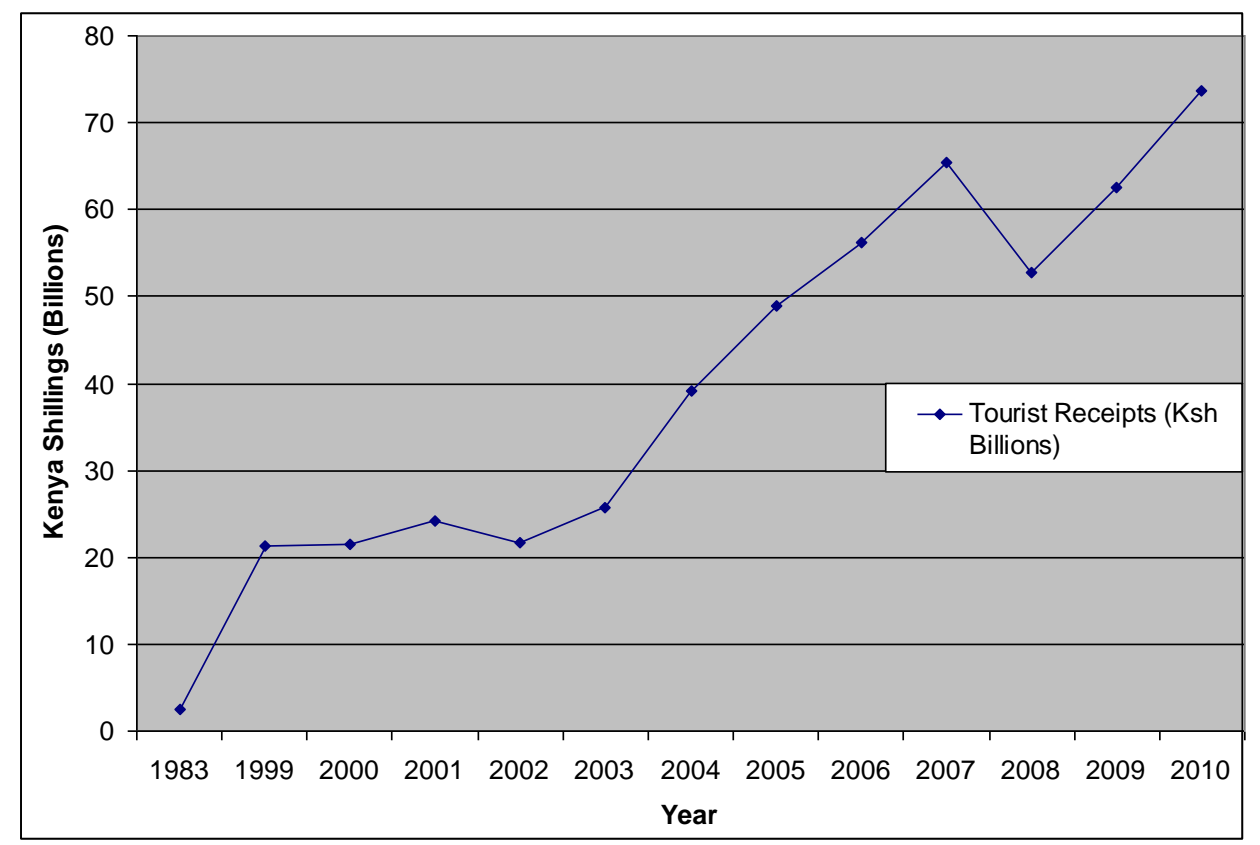

Figure 2: International Tourist Receipts in Kenya during the Period 1999-2010 as Compared to 1983 Source: Compiled from Kenya Economic Survey (Various Issues)

\section{LITERATURE REVIEW}

The causal relationship between tourism and economic growth can be explained by three varying views. The first view maintains that tourism is a major driver of economic growth, and this view is referred to as the tourism-led growth hypothesis. The second view is that economic growth strongly contributes to the growth in the tourism sector, which is referred to as the growth-led tourism hypothesis. The third view, however, argues that both tourism and economic growth Granger-cause each other. Studies that are consistent with the tourism-led growth hypothesis are Katircioglu (2010), Belloumi (2010), Lean and Tang (2010), Brida and Risso (2010), Narayan et al. (2010), Akinboade and Braimoh (2010), Chen and Chiou-Wei (2009), Brida et al. (2009), Zortuk (2009), Fayissa et al. (2008), Proenca and Soukiazis (2008), Brida et al. (2008), Croes and Vanegas (2008), Gunduz and Hatemi-J (2005), Durbarry (2004), Dritsakis (2004), and Balaguer and Cantavella-Jorda (2002). Katirciogclu (2010) examines the tourism-led growth hypothesis in Singapore using annual data from 1960 to 2007. The study finds the existence of a long-run equilibrium relationship between international tourism and economic growth, hence confirming the tourism-led growth hypothesis in the long run. Belloumi (2010) examines the causal relationship between international tourism earnings and economic growth in Tunisia using annual data for the period 1970-2007. The study shows that there is a one-way causality from tourism to economic growth. Lean and Tang (2010) examine the validity and stability of the tourism-growth causality relationship in Malaysia using the rolling subsample causality test. The results show that a causal relationship between tourism and economic growth is valid and stable over time, hence confirming the tourism-led growth hypothesis. Brida and Risso (2010) examine the relationship between tourism and economic growth in South Tyrol, Italy, using the Johansen co-integration test and the Granger causality test. The results indicate a uni-directional causality from tourism to real GDP, hence the tourism-led growth hypothesis is supported. Narayan et al. (2010) examines the contribution of tourism to the economic growth of four Pacific Island countries (Fiji, Papua New Guinea, Solomon Islands and Tonga). The results indicate that tourism increases GDP in the long and short run. Akinboade and Braimoh (2010) examine the direction of causality between international tourism earnings and long-run economic growth in South Africa using Granger causality test. The results support a uni-directional causality from international tourism earnings to real GDP in the short and long run. Using an EGARCH-M model with uncertainty factors, Chen and Chiou-Wei (2009) analyze the causal relationship between tourism expansion and economic growth in Taiwan and South Korea. The authors find a unanimous unidirectional causality from tourism to economic growth for Taiwan and a reciprocal causal relationship for South 
Korea. Brida et al. (2009) examine the contribution of tourism to Colombia's economic growth from the early 1990's until 2006. Using Johansen technique and the Granger causality test, the study finds a distinct causal flow from tourism expenditure to real per capita GDP, which supports the tourism-led growth hypothesis. Zortuk (2009) examines the contribution of the tourism sector on Turkey's economic growth using data from 1990Q1 to 2008Q3 periods. The results show the existence of a uni-directional causality from tourism development to economic development. Using panel data of 42 African countries for the period 1995-2004, Fayissa et al. (2008) examine the potential contribution of tourism to the economic growth of African economies. The results indicate that tourism greatly contributes to the current level of GDP and the economic growth of sub-Saharan African countries. Proenca and Soukiazis (2008) examine the significance of tourism as a conditioning factor of growth for four southern European countries (Greece, Italy, Portugal and Spain) and its importance in contributing to the improvement of the standard of living. The results indicate that tourism is a source of growth thus being a factor in improving the standard of living of those countries. Using quarterly data, Brida et al. (2008) examine the possible causal relationships among tourism expenditure, real exchange rate, and economic growth in Mexico. The findings of their study confirm the existence of a uni-directional causal flow from tourism expenditure to real GDP. Croes and Vanegas (2008) examine the relationship among tourism development, economic expansion and poverty reduction in Nicaragua. The authors find a one-way Granger causality from tourism development to economic expansion. Using the leveraged bootstrap causality tests, Gunduz and Hatemi-J (2005) examine whether tourism has contributed to Turkey's economic growth. The results support the tourism-led growth hypothesis. Using co-integration and causality tests, Durbarry (2004) examines the impact of tourism on Mauritian economic growth. The author finds that tourism has a significant positive impact on Mauritian economic development. Dritsakis (2004) examines the impact of tourism on the long-run economic growth in Greece. The study shows that international tourism earnings cause economic growth with a 'strong causal' relationship, while economic growth causes international tourism earnings with a 'simply causal' relationship. Balaguer and Cantavella-Jorda (2002) examine the role of international tourism in Spain. The results prove that there exists a long-run stable relationship between economic growth and tourism expansion. The results also confirm the existence of a tourism-led growth hypothesis. Studies that are consistent with the growth-led tourism hypothesis include Odhiambo (2011), Payne and Mervar (2010), Katircioglu (2009a), Lee (2008), and Oh (2005). Using the newly developed ARDL-Bounds testing approach, Odhiambo (2011) examines the relevance of the tourism-led growth hypothesis for Tanzania. The author finds that there is a short-run bi-directional causality between tourism development and economic growth and a distinct long-run uni-directional causal flow from economic growth to tourism development. The study concludes that tourism-led growth is only applicable to Tanzania in the short run; however, in the long run, it is growth-led tourism hypothesis that dominates. Payne and Mervar (2010) examine the tourism-led growth hypothesis for Croatia using quarterly data from 2001:1 to 2008:3. The results prove that there is a positive uni-directional causality from real GDP to international tourism revenues. Katircioglu (2009a) examines a long-run equilibrium between tourism, trade and real income growth in Cyprus. The author finds that real income growth stimulates growth in international trade and international tourist arrivals to the island. Using the bounds testing approach, Lee (2008) examines the short and long-run relationship between tourism and economic growth in Singapore. The findings of the study show that there is a uni-directional Granger causality from economic growth to tourism, thereby supporting the growth-led tourism hypothesis in Singapore. Oh (2005) examines the causal relations between tourism growth and economic expansion in the Korean economy. The results reveal that there is a one-way causal flow from economic growth to tourism development. Studies that are consistent with the bi-directional causality between tourism and economic growth are Seetanah (2011), Katircioglu (2009b), and Kim et al. (2006). Seetanah (2011) examines the contribution of tourism potential to economic growth and development in 19 island economies. The results indicate that tourism significantly contributes to the economic growth of these island economies and that there is a bi-causal relationship between tourism and growth. Katircioglu (2009b) analyzes the relationship between international tourism and economic growth in Malta and the direction of causality. The author concludes that both the tourism-led growth and outputdriven tourism hypotheses can be inferred for Malta. Kim et al. (2006) test the causal relationship between tourism expansion and economic development in Taiwan. The results prove a long run equilibrium relationship and bidirectional causality between the two variables. 


\section{ESTIMATION TECHNIQUES AND EMPIRICAL ANALYSIS}

The ARDL-model used in this study can be expressed as follows:

$$
\begin{aligned}
& \triangle \text { InINTERTOUR }{ }_{t}=\phi_{0}+\sum_{i=1}^{n} \phi_{1 i} \Delta \operatorname{InINTERTOUR}_{t-i}+\sum_{i=0}^{n} \phi_{2 i} \Delta \operatorname{Iny} / N_{t-i}+\sum_{i=0}^{n} \phi_{2 i} \Delta \operatorname{InTRADEVL} L_{t-i} \\
& +\phi_{3} \operatorname{InINTERTOUR}_{t-1} \phi_{3} \operatorname{InTRADEVL}_{t-1}+\phi_{4} \operatorname{Iny} / N_{t-1}+\mu_{t}
\end{aligned}
$$

$\Delta$ Iny $/ N_{t}=\delta_{0}+\sum_{i=1}^{n} \delta_{1 i} \Delta$ Iny $/ N_{t-i}+\sum_{i=0}^{n} \delta_{2 i} \Delta$ InINTERTOUR $t_{t-i}+\sum_{i=0}^{n} \delta_{2 i} \Delta \operatorname{InTRADEVL} L_{t-i} \delta_{3} \operatorname{Iny}_{\text {In }} N_{t-1}$

$$
+\delta_{4} \operatorname{InTRADEVL} \mathrm{L}_{t-1}+\delta_{4} \operatorname{InINTERTOUR_{t-1}}+\mu_{t}
$$

$\triangle$ InTRADEVL $_{t}=\delta_{0}+\sum_{i=1}^{n} \delta_{1 i} \Delta \operatorname{InTRADEVL}_{t-i}+\sum_{i=0}^{n} \delta_{2 i} \Delta \operatorname{InINTERTOUR}_{t-i}+\sum_{i=0}^{n} \delta_{2 i} \Delta$ Iny $/ N_{t-i}+$

$+\delta_{4} \operatorname{InTRADEVL}_{t-1}+\delta_{4} \operatorname{InINTERTOUR}_{t-1}+\delta_{3} \operatorname{Iny} / N_{t-1}+\mu_{t}$

where InINTERTOUR $=\log$ of tourism variable; Iny/N $=\log$ of real GDP per capita; TRADEVL $=\log$ of real trade volume (exports plus imports); $\mu_{\mathrm{t}}=$ white noise error term; and $\Delta=$ first difference operator.

The ARDL-bounds testing procedure used in this study is based on the joint F-statistic, which has nonstandard asymptotic distribution. According to Pesaran and Pesaran (1997) and Pesaran et al. (2001), there are two sets of critical values for a given significance level. The first set of critical values assumes that all the variables included in the ARDL-model are I(0), while the second set assumes that the variables are I(1). If the F-statistic is found to be lower than the lower-bounds value, then the null hypothesis of no cointegration cannot be rejected. However, if the computed test statistic exceeds the upper critical bounds value, then the Ho hypothesis is rejected and the variables are considered to be cointegrated. However, if the F-statistic falls into the bounds, then the cointegration test is considered to be inconclusive.

Once the long-run relationship between tourism development, trade volume and economic growth is confirmed, the next step is to examine the short-run and long-run causality between the three variables using the following model (Odhiambo, 2009b; Narayan and Smyth, 2008; and Odhiambo, 2010).

$$
\begin{aligned}
& \triangle \operatorname{InINTERTOUR} R_{t}=\phi_{0}+\sum_{i=1}^{n} \phi_{1 i} \Delta \operatorname{InINTERTOUR} R_{t-i}+\sum_{i=0}^{n} \phi_{2 i} \Delta \operatorname{Iny} / N_{t-i} \\
& +\sum_{i=0}^{n} \phi_{1 i} \Delta \operatorname{InTRADEVL} L_{t-i}+\operatorname{ECM}_{t-1}+\mu_{t} \\
& \Delta \text { Iny } / N_{t}=\delta_{0}+\sum_{i=1}^{n} \delta_{1 i} \Delta \text { Iny } / N_{t-i}+\sum_{i=0}^{n} \delta_{2 i} \Delta I N T E R T O U R_{t-i}+\sum_{i=0}^{n} \delta_{2 i} \Delta T R A D E V L_{t-i} \\
& +E C M_{t-1}+\mu_{t} \\
& \triangle \operatorname{InTRADEVL} \mathrm{T}_{t}=\delta_{0}+\sum_{i=1}^{n} \delta_{1 i} \Delta \operatorname{InTRADEVL} L_{t-i}+\sum_{i=0}^{n} \delta_{2 i} \Delta \operatorname{INTERTOUR_{t-i}}+\sum_{i=0}^{n} \delta_{2 i} \Delta y / N_{t-i} \\
& +E C M_{t-1}+\mu_{t}
\end{aligned}
$$

where $\mathrm{ECM}_{\mathrm{t}-1}=$ the lagged error-correction term obtained from the long-run equilibrium relationship. 
The direction of the causality between INTERTOUR, TRADEVL and $y / N$ in equations (4), (5) and (6) can therefore be determined by the F-statistic and the lagged error-correction term. While the $t$ statistic on the coefficient of the lagged error-correction term represents the long-run causal relationship, the F-statistic represents the short-run causal effect (Odhiambo, 2009b; and Narayan and Smyth, 2006). It is also important to note that even though the error-correction term has been incorporated in all the causality equations, only the equation(s) where the null hypothesis of no cointegration is rejected will be estimated with an error-correction term (Narayan and Smyth, 2006; Morley, 2006; and Odhiambo, 2009a).

\section{Data Source and Definition of Variables}

- $\quad$ Tourism Development: This variable is defined as the number of international tourist arrivals in Kenya. The data for this variable was obtained from various issues of the World Development Indicators and the African Statistical Yearbook.

- $\quad$ Trade Volume: This variable is defined as real trade volume (exports plus imports) and the data was obtained from the World Development Indicators.

- $\quad$ Economic Growth $(y / N)$ : this variable was proxied by the real GDP per capita and the data were obtained from the World Development Indicators.

\section{Stationarity Tests}

The stationarity tests were conducted in two stages - stationarity tests in levels and stationarity tests on first difference. The stationarity tests in levels (not presented here) show that all variables are non-stationary in levels. However, when the stationarity tests were conducted on differenced variables, using Phillips-Perron and DickeyFuller-GLS Tests, all variables were found to be stationary (Table 1).

Table 1: Stationarity Tests of Variables on first Difference

\begin{tabular}{|l|c|c|}
\hline Stationarity Tests of Variables on first Difference - Phillips-Perron (PP) Test \\
\hline Variable & No Trend & Trend \\
\hline DLy/N & $-5.269097^{* * *}$ & $-5.574245^{* * *}$ \\
\hline DLINTERTOUR & $-6.047790^{* * *}$ & $-5.947292^{* * *}$ \\
\hline DLTRADEVL & $-6.301430^{* * *}$ & $-6.179072^{* * *}$ \\
\hline Stationarity Tests of Variables on first Difference - Dickey-Fuller - GLS Test \\
\hline DLy/N & $-2.901555^{* * *}$ & $-3.783264 * * *$ \\
\hline DLINTERTOUR & $-6.038825^{* * *}$ & $-6.104039^{* * *}$ \\
\hline DLTRADEVL & $-4.602841^{* * *}$ & $-5.970894 * * *$ \\
\hline
\end{tabular}

\section{Notes:}

1) The truncation lag is based on Newey and West (1987) bandwidth.

2) $\quad * * *$ denotes statistical significance at the $1 \%$ level.

The results reported in Table 1 show that all the three variables are integrated of order one and not order two or higher.

\section{Cointegration Test}

Since the unit root results have confirmed that all the variables used in this study are integrated of order one, we can now proceed with the ARDL-bounds testing procedure to examine the long-run relationship between tourism development, trade, and economic growth in Kenya. The ARDL-bounds test involves two steps. In the first step, the order of lags on the first difference variables in equations (1)-(3) are obtained from the unrestricted models by using the Akaike Information Criterion (AIC) and the Schwartz Bayesian Criterion (SBC). The results of the AIC and SBC tests (not reported here) show that the optimal lag, in the case of economic growth and trade equations, is lag one (1), while in the case of the tourism development equation, the optimal lag is lag 2 . Once the optimal lags are established, the second step is to apply the bounds F-test to equations (1)-(3) in order to establish a cointegration relationship between the three variables. These results are reported in Table 2. 
Table 2: Bounds F-test for Cointegration

\begin{tabular}{|c|c|c|c|c|c|c|}
\hline Dependent variable & \multicolumn{3}{|c|}{ Function } & \multicolumn{3}{|c|}{ F-test statistic } \\
\hline$y / N$ & \multicolumn{3}{|c|}{ y/N(INTERTOUR, TRADEVL) } & \multicolumn{3}{|c|}{$6.5241 * * *$} \\
\hline In INTERTOUR & \multicolumn{3}{|c|}{ INERTOUR(y/N, TRADEVL) } & \multicolumn{3}{|c|}{1.4520} \\
\hline In TRADEVL & \multicolumn{3}{|c|}{ TRADEVL(INTERTOUR, y/N) } & \multicolumn{3}{|c|}{$4.7074 * *$} \\
\hline \multicolumn{7}{|l|}{ Asymptotic Critical Values } \\
\hline & \multicolumn{2}{|l|}{$1 \%$} & \multicolumn{2}{|l|}{$5 \%$} & \multicolumn{2}{|l|}{$10 \%$} \\
\hline & $\mathrm{I}(0)$ & $\mathrm{I}(1)$ & $\mathrm{I}(0)$ & $\mathrm{I}(1)$ & $\mathrm{I}(0)$ & $\mathrm{I}(1)$ \\
\hline Pesaran et al. (2001), p. 300, Table CI(ii) Case II & 4.13 & 5.00 & 3.10 & 3.87 & 2.63 & $3 . .35$ \\
\hline
\end{tabular}

Note: $* * *$ and $* *$ denote $1 \%$ and $5 \%$ level of significance, respectively.

The results reported in Table 2 show that there are two cointegrating vectors between $\mathrm{y} / \mathrm{N}$, INTERTOUR and TRADEVL. This is confirmed by the calculated F-statistics in $\mathrm{y} / \mathrm{N}$ and TRDEVL equations which are higher than the upper-bound critical values.

\section{Analysis of Causality Test Based on the Error-Correction Model}

The results reported in section 4.5 show that there is a long-run relationship between tourism development, trade, and economic growth in Kenya. In this section, we use a modified version of Granger causality to examine the causal relationship between tourism development, trade, and economic growth in Kenya. The causality, in this case, is examined through the significance of the coefficient of the lagged error-correction term and the F-statistic or the Wald test. The results of the causality tests are reported in Table 3.

Table 3: Granger Non-causality Test

\begin{tabular}{|c|c|c|c|c|}
\hline F-statistics [P-value] & & & & t - statistics \\
\hline Dependent variable & $\Delta \operatorname{In} \mathbf{y} / \mathbf{N}_{\mathrm{t}}$ & $\Delta$ InINTERTOUR $_{\mathrm{t}}$ & $\Delta$ InTRADEVL $_{t}$ & $\mathbf{E C M}_{\mathrm{t}-1}$ \\
\hline$\Delta \operatorname{Iny} / \mathbf{N}_{\mathrm{t}}$ & - & $5.1275[0.0081]^{* * *}$ & $5.7357[0.0055]^{* * *}$ & $\begin{array}{c}-4.913 * * * \\
{[0.0017]}\end{array}$ \\
\hline$\Delta$ InINTERTOUR $_{\mathbf{t}}$ & $1.3299[0.3227]$ & - & $0.81684[0.5044]$ & \\
\hline$\Delta$ InTRADEVL $_{t}$ & $1.099[0.4168]$ & $4.5323[0.0126] * * *$ & - & $\begin{array}{c}-4.083 * * * \\
{[0.0065]}\end{array}$ \\
\hline
\end{tabular}

Note: $* * *$ denotes statistical significance at the $1 \%$ level.

The results reported in Table 3 show that there is a distinct uni-directional causal flow from tourism development to economic growth in Kenya. This applies irrespective of whether the causality is estimated in the short run or in the long run. The long-run causality is supported by the error correction term in the economic growth equation, which is negative and statistically significant. The short-run causality, on the other hand, is supported by the F-statistic in the $\mathrm{y} / \mathrm{N}$, which is statistically significant, as was expected. The results also show that there is a long-run and short-run causal flow from trade to economic growth in Kenya. This finding is supported by the corresponding F statistic, which is statistically significant. Other results show that international tourism Grangercauses trade in Kenya, both in the short and the long run.

\section{CONCLUSION}

This paper examines the causal relationship between tourism development and economic growth in Kenya using the recently introduced ARDL-bounds testing approach. In order to address the weakness associated with the bi-variate causality models, the current study includes trade as a third important variable between economic growth and international tourism, thereby leading to a simple trivariate model. The study attempts to answer one critical question - "Does the development of tourism sector in Kenya leads to economic growth?" The results show that there is a distinct uni-directional causal flow from tourism development to economic growth in Kenya. This applies irrespective of whether the causality is estimated in the short or in the long run. The results also show that there is a short-run and long-run uni-directional causal flow from trade to economic growth in Kenya. Likewise, the results show that international tourism Granger-causes trade in Kenya, both in the short and in the long run. 


\section{AUTHORS' INFORMATION}

Obadiah N. Kibara is a PhD (Tourism Management) candidate at the University of South Africa, Pretoria. He holds a Master of Science degree in Tourism Management from the University of Surrey, England, UK. Mr Kibara has a wealth of experience in the fields of tourism education and management, having held various academic and management positions in Kenya, Botswana and South Africa. He is currently a lecturer in Tourism Management at the University of South Africa (UNISA). Email: kibaron@unisa.ac.za.

Professor Nicholas M Odhiambo holds a PhD (Economics) degree from Stellenbosch University (South Africa) and a Masters degree in Economics from the University of Dar-es-salaam (Tanzania). He is an NRF-rated researcher, and is listed in a number of international bibliographies and databases. He is currently working as Professor of Economics and Chair of Growth, Poverty and Policy Modelling Research (GPPMR) flagship at the University of South Africa (UNISA). E-mail: odhianm@unisa.ac.za. Corresponding author.

Josephine M. Njuguna is a Lecturer in Investment Management at the University of South Africa, Pretoria. She holds a postgraduate degree in Financial Management from the University of Pretoria (South Africa). E-mail: njugujm@unisa.ac.za

\section{REFERENCES}

1. Akama, J. S. (1999), “The Evolution of Tourism in Kenya”, Journal of Sustainable Tourism 7(1): 6-25.

2. Akinboade, O. A. and Braimoh, L. A. (2010), "International Tourism and Economic Development in South Africa. A Granger Causality Test", International Journal of Tourism Research 12: 149-163.

3. Balaguer, J. and Cantavella-Jorda, M. (2002), "Tourism as a Long-Run Economic Growth Factor: The Spanish Case", Applied Economics 34(7): 877-884.

4. Belloumi, M. (2010), "The Relationship Between Tourism Receipts, Real Effective Exchange Rate and Economic Growth in Tunisia", International Journal of Tourism Research 12(5): 550-560.

5. Brida, J. G., Carrera, E. J. S. and Risso, W. A. (2008), “Tourism's Impact on Long-Run Mexican Economic Growth", Economics Bulletin 3(21): 1-8.

6. Brida, J. G., Pereyra, J. S., Risso, W. A., Devesa, M. J. S. and Aguirre, S. Z. (2009), “The Tourism-Led Growth Hypothesis: Empirical Evidence from Colombia", Tourismos: An International Multidisciplinary Journal of Tourism 4(2): 13-27.

7. Brida, J. G. and Risso, W. A. (2010), “Tourism as a Determinant of Long-Run Economic Growth”, Journal of Policy Research in Tourism, Leisure and Events 2(1): 14-28.

8. Chen, C-F. and Chiou-Wei, S. Z. (2009), "Tourism Expansion, Tourism Uncertainty and Economic Growth: New Evidence from Taiwan and Korea", Tourism Management 30: 812-818.

9. Croes, R. and Vanegas Sr., M. (2008), "Cointegration and Causality Between Tourism and Poverty Reduction”, Journal of Travel Research 47: 94-103.

10. Dieke, P. U. (1991), "Policies for Tourism Management in Kenya”, Annals of Tourism Research 9: 69-90.

11. Dritsakis, N. (2004), "Tourism as a Long-Run Economic Growth Factor: An Empirical Investigation for Greece Using Causality Analysis", Tourism Economics 10(3): 305-316.

12. Durbarry, N. (2004), "Tourism and Economic Growth: The Case of Mauritius", Tourism Economics 10(4): 389-401.

13. Fayissa, B., Nsiah, C. and Tadasse, B. (2008), "Impact of Tourism on Economic Growth and Development in Africa", Tourism Economics 14(4): 807-818.

14. Government of Kenya. 1970. National Development Plan. Nairobi: Government Printer.

15. Government of Kenya. Economic Survey. (Various Issues). Nairobi: Government Printer.

16. Government of Kenya. 2003. Economic Recovery Strategy for Wealth and Employment Creation 2003 2007. Nairobi: Government Printer.

17. Government of Kenya. 2006. National Tourism Policy, Final Draft. Nairobi: Government Printer.

18. Government of Kenya. 2010. Tourism Act 2010. Nairobi: Government Printer.

19. Gunduz, L. and Hatemi, J. A. (2005) “Is the Tourism-Led Growth Hypothesis Valid for Turkey?", Applied Economics Letters 12(8): 499-504. 
20. Katircioglu, S. (2009a), "Tourism, Trade and Growth: The Case of Cyprus”, Applied Economics 41(21): 2741-2750.

21. Katircioglu, S. T. (2009b), "Testing the Tourism-Led Growth Hypotheses: The Case of Malta”, Acta Oeconomica 59(3): 331-343.

22. Katircioglu, S. (2010), "Research note: Testing the Tourism-Led Growth Hypothesis for Singapore - An Empirical Investigation from Bounds Test to Cointergration and Granger Causality Tests", Tourism Economics 16(4): 1095-1101.

23. Kim, H. J., Cheng, M-H. and Jang, S. S. (2006), “Tourism Expansion and Economic Development: The Case of Taiwan" Tourism Management 27: 925-933.

24. Lean, H. H. and Tang, C. F. (2010), "Is the Tourism-Led Growth Hypothesis Stable for Malaysia? A Note", International Journal of Tourism Research 12: 375-378.

25. Lee, C. G. (2008), "Tourism and Economic Growth: The Case of Singapore”, Regional and Sectoral Economic Studies 8(1): 89-98.

26. Morley, B. (2006), "Causality Between Economic Growth and Migration: An ARDL Bounds Testing Approach", Economics Letters 90: 72-76.

27. Narayan, P. K., Narayan, S., Prasad, A. and Prasad, B. C. (2010), "Tourism and Economic Growth: A Panel Data Analysis for Pacific Island Countries", Tourism Economics 16(1): 169-183.

28. Narayan, P. K. and Smyth, R. (2006), "Higher Education, Real Income and Real Investment in China: Evidence from Granger Causality Tests", Education Economics 14: 107-125.

29. Narayan, P. K. and Smyth, R. (2008), "Energy Consumption and Real GDP in G7 Countries: New Evidence from Panel Cointegration with Structural Breaks", Energy Economics 30: 2331-2341.

30. Newey, W. K. and West, K. D. (1987), "A Simple, Positive Semi-Definite, Heteroskedasticity and Autocorrelation Consistent Covariance Matrix", Econometrica 55: 703-708.

31. Odhiambo, N. M. (2009a), "Energy Consumption and Economic Growth in Tanzania: An ARDL Bounds Testing Approach", Energy Policy 37(2): 617-622.

32. Odhiambo, N. M (2009b), "Savings and Economic Growth in South Africa: A Multivariate Causality Test" Journal of Policy Modelling 31(5): 708-718.

33. Odhiambo, N. M. (2010), "Finance-Investment-Growth Nexus in South Africa: An ARDL-Bounds Testing Approach", Economic Change and Restructuring 43(3): 205-219.

34. Odhiambo, N. M. (2011), "Tourism Development and Economic Growth in Tanzania: Empirical Evidence from the ARDL-Bounds Testing Approach", Economic Computation and Economic Cybernetics Studies and Research 45(3): 71-83.

35. Oh, C-O. (2005), "The Contribution of Tourism Development to Economic Growth in the Korean Economy", Tourism Management 26: 39-44.

36. Ouma, J. P. B. M. 1970. Evolution of Tourism in East Africa. Nairobi, East African Literature Bureau.

37. Payne, J. E. and Mervar, A. (2010), "Research note: The Tourism-Growth Nexus in Croatia”, Tourism Economics 16(4): 1089-1094.

38. Pesaran, M. and Pesaran, B., 1997. Working with microfit 4.0: Interactive economic analysis, Oxford University Press, Oxford.

39. Pesaran, M., Shin, Y. and Smith, R. (2001), "Bounds Testing Approaches to the Analysis of Level Relationships", Journal of Applied Econometrics 16: 289-326.

40. Proenca, S. and Soukiazis, E. (2008), “Tourism as an Economic Growth Factor: A Case Study for Southern European Countries", Tourism Economics 14(4): 791-806.

41. Rajotte, F. (1983), "The Role of Tourism in African Development: The Kenyan Case", Indian Geographical Studies, Research Bulletin 15:1-15.

42. Seetanah, B. (2011), “Assessing the Dynamic Economic Impact of Tourism for Island Economies", Annals of Tourism Research 38(1): 291-308.

43. Vanegas, M., and R. Croes (2003). "Growth, Development and Tourism in a Small Economy: Evidence from Aruba." International Journal of Tourism Research, 5: 315-30.

44. Vanegas, M., and R. Croes (2004). "Turismo Como Instrumento de Expansión Económica y Reducción de Pobreza." Policy discussion paper, July. Managua: Office of the President of Nicaragua and Nicaragua Institute of Tourism. 
45. Yamakawa, R., 2007. Poverty Reduction through Tourism: The experiences in Asia (online). United Nations Economic and Social Commission for Asia and the Pacific. Workshop on expanding the role of tourism in Poverty reduction. http://www.unescap.org/EPOC/meetings/WkshpPovertyReduction/English/PovertyReduction(RY).ppt\#375,4 (accessed September 2009)

46. Zortuk, M. (2009), “Economic Impact of Tourism on Turkey's Economy: Evidence from Cointegration Tests" International Research Journal of Finance and Economics 25: 231-239. 
NOTES 